\title{
COVID-19 and Sudan: The Impact on Economic and Social Rights in the Context of a Fragile Democratic Transition and Suspended Constitutionalism
}

\author{
Mohamed Abdelsalam Babiker* \\ University of Khartoum, Khartoum, Sudan \\ mobabiker@uofk.edu
}

\begin{abstract}
This article argues that the lockdown imposed in Sudan due to the COVID-19 pandemic has seriously affected the livelihood of vulnerable populations and their right to live a dignified life. It explores how emergency measures were aimed at containing the spread of the pandemic. The article argues that these measures have seriously affected the enjoyment of core economic and social rights, particularly in the context of a weak legislative framework of social protection. It concludes by arguing that Sudan's transitional government is not subject to parliamentary scrutiny and exercises legislative and executive powers that are de facto illegitimate, as they are not subject to review by the courts and because of the current suspension of constitutional organs and governance structures. This incomplete governance structure is concerning from a rule of law perspective and has prevented scrutiny of COVID-19 emergency measures, particularly those affecting the basic rights of vulnerable groups.
\end{abstract}

\section{Keywords}

COVID-19, economic and social rights, political transition, rule of law, Constitutional Declaration

\section{INTRODUCTION}

Sudan's peaceful revolution in 2018 created fresh hope for a democratic Sudan where the rule of law and constitutionalism could be observed. The Constitutional Declaration 2019 agreed between the Transitional Military Council and the Freedom and Change Movement constitutes the main constitutional framework governing the three-year transitional period. ${ }^{1}$ During this

Associate professor of law, Faculty of Law, University of Khartoum.

1 On 3 October 2020 the Sudanese government signed the Juba Peace Agreement with armed opposition groups, which extended the transitional period until 2023. The agreement amended the Constitutional Declaration 2019. See Constitutional Declaration 2019 (amendments 2020) (2 November 2020) 1908 Sudan Official Gazette 1. 
period, the fundamental transformation supposed to take place includes the adoption of a permanent constitution, the conclusion of peace agreements with the rebel groups, comprehensive law reform, transitional justice measures, institutional reforms (juridical, security and electoral reform) and a general election. However, since its formation in September 2019, the transitional government has faced a number of challenges, several of which have been caused, or aggravated by COVID-19.

The first case of COVID-19 in Sudan was diagnosed on 12 March 2020, in a 50-year-old Sudanese male who had arrived by air from the United Arab Emirates. He developed respiratory symptoms, was admitted to hospital and died three days later with a positive COVID-19 RT-PCR test. This raised the alarm that SARS-CoV-2 had arrived in Sudan. ${ }^{2}$ Sudan declared a state of health emergency on 16 March 2020 and the health authorities closed the airport and other points of entry. The government imposed a lockdown on Khartoum State from 24 April to 8 July 2020 . Social distancing was put in place and public gatherings were suspended. The Ministry of Health, as well as national and international actors, responded to the health emergency with a series of measures, both to prevent the spread of the disease (including the lockdown and the closing of public spaces and markets) and to treat and cater for those affected by the pandemic. ${ }^{3}$ The latter consisted in particular of support measures for vulnerable households and informal workers, refugees, asylum seekers and internally displaced persons. ${ }^{4} \mathrm{~A}$ number of steps were taken to alleviate the consequences of restrictive measures on those most in need, including vulnerable households living on the peripheries of Khartoum State, and informal workers and daily wage labourers across the country. The food baskets distributed in the outskirts of Khartoum targeted all residents, regardless of their nationality or legal status. However, the supportive emergency protection schemes for persons living in poverty and marginalized people proved insufficient to enable them to lead a dignified life throughout the pandemic. ${ }^{5}$ Consequently, the community resisted the lockdown because

2 See MM Mukhtar and M Khogali "The accelerating COVID-19 epidemic in Sudan" (2021) 22 Nature Immunology 797, available at: <https://doi.org/10.1038/s41590-02100950-0> (last accessed 14 August 2021).

3 Other efforts were implemented by the Ministry of Labor and Social Development in coordination with UN agencies, donors and non-governmental organizations to address the socio-economic impact of the crisis.

4 Refugees and irregular migrants have equally benefited from this support. More than 34,000 refugee households have benefited from in-kind support: "Sudan: IPC acute food insecurity analysis: June 2019-August 2019" (September 2019, Integrated Food Security Phase Classification), available at: <https://reliefweb.int/report/sudan/sudan-ipc-acute-foo d-insecurity-analysis-june-2019-august-2019-issued-september-2019> (last accessed 14 August 2021); Humanitarian Needs Overview: Sudan (January 2020, Office for the Coordination of Humanitarian Assistance), available at: <https://reliefweb.int/sites/rel iefweb.int/files/resources/Sudan_2020_HNO.pdf> (last accessed 14 August 2021). Ibid. 
of increased economic hardship for families and it was not implemented effectively due to a lack of proper law enforcement. ${ }^{6}$

In the context of weak social welfare provision in Sudan and the state's inability to provide core economic and social rights (ESR), this article argues that the lockdown imposed due to the COVID-19 pandemic seriously affected the livelihood of vulnerable populations, particularly their rights to live a dignified life, to food, to shelter, and to enjoy physical and mental health. Sudan is a state party to the African Charter on Human and Peoples' Rights (African Charter), ${ }^{7}$ the International Covenant on Economic, Social and Cultural Rights (ICESCR), 8 the International Covenant on Civil and Political Rights (ICCPR) ${ }^{9}$ and other treaties that obligate it to respect, protect and promote economic, social and cultural rights (ESCR). ${ }^{10}$

Yet, Sudan's national legislative framework pertaining to ESR, before and during the COVID-19 pandemic, does not adequately ensure social protection for the populace. Sudan's social protection schemes are regarded as mere policies, directives and not legally binding and, above all, were not based on any legal philosophy of a human rights-based approach. ${ }^{11}$ Sudanese constitutions (including the recent Constitutional Declaration 2019) are also not based on a "social justice model" and ESCR have been neglected, if not altogether ignored, by both civilian and military governments throughout Sudan's history. ${ }^{12}$ Regional African human rights treaty bodies have rarely adjudicated communications related to ESR in Sudan, while UN human rights treaty bodies have

6 See Mukhtar and Khogali "The accelerating COVID-19 epidemic", above at note 2.

7 OAU doc CAB/LEG/67/3/Rev 5; (1982) 21 International Legal Materials 58 (ratified by Sudan 11 March 1986).

8993 UN Treaty Series 3 (adopted 16 December 1966, entered into force 3 January 1976, ratified by Sudan 18 March 1986).

9999 UN Treaty Series 171 (adopted 16 December 1966, entered into force 23 March 1976, ratified by Sudan 18 March 1986).

10 At the time of writing, July 2021, Sudan is a party to the following treaties: International Convention on the Elimination of All Forms of Racial Discrimination (1965) (ratified 21 March 1977); Convention on the Rights of the Child 1989 (signed 24 July 1990, ratified by Act No 80 on 3 August 1990 by a law promulgated pursuant to the Third Constitutional Degree of 1989 by the Revolution Command Council, published in Special Annex No 1542 of 15 August 1990, UN doc A./44/25.182); Convention on the Rights of Persons with Disabilities (2006) and its Optional Protocol (2006) (ratified 24 April 2009); Optional Protocol to the Convention on the Rights of the Child on the Sale of Children and Child Prostitution and Child Pornography (2000) (ratified 2 November 2004, UN GA res $54 / 263$ of 25 May 2000); Optional Protocol to the Convention on the Rights of the Child on the Involvement of Children in Armed Conflict (2000) (signed 9 May 2002, ratified 26 July 2006, UN GA res 54/263 of 25 May 2000).

11 On the Sudanese constitutional bills of rights and the absence of a rights-based approach, see MA Babiker "Human rights protection in Sudan's constitutions: A critique of bills of rights" in L Oette and MA Babiker (eds) Constitution-Making and Human Rights in the Sudans (2018, Routledge) 91. See also "Concluding observations on the second periodic report of the Sudan”, UN doc E/C.12/SDN/CO/2 (27 October 2015, Committee on ESCR).

Ibid. 
argued that there is a lack of clarity as to the legal status of ESR in the Sudanese domestic legal order. ${ }^{13}$ ESR were not incorporated into Sudan domestic legal system or enforced by the courts.

In the context of the COVID-19 pandemic and in the absence of adequate protection for vulnerable groups, an ESCR assessment of Sudan's social protection and social security legislation is urgently needed. It is imperative as a response to address present needs but also to lay a solid legal foundation for an equitable social protection framework. This includes ensuring the effective realization of minimum core human rights capable of protecting vulnerable groups, particularly women, children and workers in the informal economy.

The COVID-19 pandemic reached Sudan at a critical stage during the first year of the post-revolutionary transitional period, when most of the envisaged reforms had yet to commence. Significantly, this comprised the establishment of transitional governance structures and institutions: the Transitional Legislative Council (TLC), the High Judicial Council, the Constitutional Court and independent commissions, which were meant to provide the legal and institutional framework for the transition. In their absence, COVID-19 measures were conceived and implemented by a newly formed transitional government, which lacked experience of managing and coordinating major crises, certainly at the scale of the COVID-19 emergency.

Against this background, this article explores how the emergency measures in response to COVID-19 affected the political transition and, conversely, how the delayed political transition impacted responses to the pandemic. In order to contain the spread of COVID-19, the transitional government restricted freedom of assembly and association by banning some public demonstrations. Such emergency measures were not intended to stifle criticism or restrict the civic space and thwart the political transition. Rather, the article argues that the emergency measures were aimed at containing the spread of the lethal pandemic in a proportional manner, both in degree and duration, and as strictly as possible to deal with the threat to "the life of the nation".

However, from an ESCR-based perspective, the COVID-19 emergency measures have seriously affected the enjoyment of core ESR. The right to work was restricted, while access to health services was diminished due to the diversion of vital resources to deal with the pandemic. Patients were not able to access hospitals for the treatment of life-threatening illnesses or to receive essential lifesaving drugs. ${ }^{14}$ While lockdown affected the daily livelihood of

13 See "Concluding observations", above note 11 at 2, paras 5-8; "Concluding observations on Sudan's ICESCR initial report”, UN doc E/C.12/1/Add.48 (1 September 2000), paras 17 and 29; "Report of special rapporteur on the situation of human rights in the Sudan to the Human Rights Commission”, UN doc E/CN.4/1999/38/Add.1 (17 May 1999), para 25.

14 The pandemic has had an impact on health services. Patients with chronic diseases and those who required emergency medical interventions were affected. Most public and private clinics were closed due to the high infection and mortality rates among healthcare providers. COVID-19 isolation centres and intensive care services were overwhelmed due 
vulnerable populations living below the poverty line, the government not only failed to cater for their basic needs, but also implemented unprecedented economic liberalization policies that displayed no concern for the impact on persons living in poverty and other vulnerable groups. ${ }^{15}$ Taking an ESCR-based approach, the article argues that the mere existence of the epidemic does not simply give states carte blanche to derogate from ESCR, particularly in such novel situations, especially where the state may violate or restrict the enjoyment of core rights provided for in the ICESCR.

The article concludes by arguing that, as the transitional government is not subject to parliamentary scrutiny, it exercises legislative powers that are de facto illegitimate as they are not subject to scrutiny by the Constitutional Court. This incomplete governance structure is concerning from a rule of law perspective. It has prevented scrutiny of COVID-19 emergency measures, executive decrees and decisions, particularly those affecting basic ESCR of vulnerable groups. These developments demonstrate the detrimental impact of the lack of a timely political transition (at least in part caused by COVID-19) on rights, the protection of which has been jeopardized by the pandemic.

\section{COVID-19 AND ITS IMPACT ON ECONOMIC AND SOCIAL RIGHTS}

By the time of the COVID-19 outbreak, Sudan's health system was in a fragile state. This was the result of a systemic long-term deterioration, further exacerbated by the worsening socio-economic situation. ${ }^{16}$ These circumstances weakened the ability of large sections of vulnerable populations already living on the margins of society to cope. Since March 2020, thousands of lives have been lost, education opportunities have disappeared, businesses have closed, and every aspect of human and economic development has been impaired. ${ }^{17}$ The pandemic has also seriously impacted children who are included in the

contd

to the lack of sufficient beds and ventilators. See Mukhtar and Khogali "The accelerating COVID-19 epidemic", above at note 2.

15 N Elhennawy "IMF endorses Sudan's reform plan for battered economy" (24 September 2020) Washington Post, available at: <https://www.washingtonpost.com/world/africa/imfendorses-sudans-reform-plan-for-battered-economy/2020/09/24/42770a22-fe5c-11ea-b0e4350e4e60cc91_story.html> (last accessed 14 August 2021).

16 In late 2019, a total of 5.8 million people in Sudan suffered from extreme poverty and severe acute food insecurity. Rising destitution was reflected in the number of people needing humanitarian assistance, which rose from 5.2 million in 2015 to 9.3 million in 2020, an increase of more than 75\%: "Sudan: IPC acute food insecurity analysis", above at note 4; and Humanitarian Needs Overview, above at note 4.

17 See statement of UN experts on COVID-19 on the occasion of the 34th anniversary of the UN Declaration on the Right to Development: "International community must act now and together to prevent development setback" (4 December 2020) (copy on file with the author). 
increasing number of people requiring humanitarian assistance. ${ }^{18}$ Systemic public health deficiencies have contributed to and aggravated these variegated impacts. In 2015, the Committee on ESCR raised the issue of access to healthcare in Sudan and safe and affordable medicines, as well as disparities in access to healthcare, given that those who are well-off have access to better quality services in private healthcare facilities. ${ }^{19}$ Half of the population does not have access to basic health services, while a third of public health facilities are not fully functioning, due to staff shortages, poor physical infrastructure and an insufficient number of healthcare facilities. ${ }^{20}$ These poor health services, in addition to overcrowding and a lack of access to basic water and sanitation, have facilitated the spread of the pandemic, further marginalizing hundreds and thousands of Sudanese and their enjoyment of ESCR.

COVID-19 related health measures, particularly the lockdown, severely affected poor communities in the service sector in Sudan. This sector absorbs over a million workers, mostly in low-income and casual jobs, the majority of whom lack access to financing and basic health emergency services. ${ }^{21}$ Restrictions and the resulting decrease in economic activity particularly affected the informal hospitality sector and those in the informal economy, although no official data is available to allow a detailed assessment of the impact. The loss of employment opportunities was compounded by the recent decision of the transitional government, in response to pressure by international financial institutions, to liberalize the fragile economy and lift subsidies without putting in place social protection schemes. ${ }^{22}$ The rising levels of poverty and vulnerability resulting from these developments have led to protests and may, if left unaddressed, compromise Sudan's democratic transition. ${ }^{23}$ The deteriorating economic situation and its impact on a substantial part of the population risks creating political instability that would complicate Sudan's pathway to a democratic society, rule of law and constitutionalism.

18 Well before the outbreak of the COVID-19 pandemic, in Sudan over 2.7 million children were suffering from acute malnutrition: Humanitarian Needs Overview, above at note 4 .

19 "Concluding observations", above at note 11, para 51.

20 The committee drew Sudan's attention to its General Comment No 14 (2000) on the Right to the Highest Attainable Standard of Health: id, paras 51 and 52.

21 See A Roadmap Toward a National Employment Policy for Sudan (January 2014, UN Development Programme / International Labour Organization), available at: < https:// www.ilo.org/wcmsp5/groups/public/ - africa/ - ro-abidjan/ - sro-cairo/documents/publ ication/wcms_334878.pdf> (last accessed 14 August 2021).

22 "Sudan to continue the liberalization of its economy" (11 June 2021) Dabanga, available at: <https://www.dabangasudan.org/en/all-news/article/sudan-to-continue-the-liberalis ation-of-its-economy> (last accessed 14 August 2021).

23 K Abdelaziz "Worsening power cuts show depth of Sudan's economic challenge" (30 June 2021) Reuters, available at: <https://www.reuters.com/world/africa/worsening-po wer-cuts-show-depth-sudans-economic-challenge-2021-06-30/> (last accessed 14 August 2021). 
A series of structural factors, which had already been severely affecting Sudan's economic situation over the last decade, ${ }^{24}$ left Sudan vulnerable to the impact of COVID-19. Sudan's crippling economy has been marred by the loss of revenue following the secession or independence of South Sudan in 2011 and corruption. In addition, the US-imposed economic sanctions had, before their recent lifting, virtually cut Sudan off from the international financial system and deterred foreign investment, thereby negatively affecting people's right to education and other human rights. ${ }^{25}$ The protracted armed conflicts in several regions in Sudan have also caused massive internal displacement and diverted substantial resources to war efforts rather than to the provision of ESR. The former regime of Omer Al Bashir has therefore left behind a pernicious legacy of a serious economic crisis and debts for Sudan. All these factors, including the COVID-19 pandemic, have increased poverty and the vulnerability of large sections of Sudan's population.

\section{ESCR IN SUDAN'S LEGISLATIVE FRAMEWORK}

In the COVID-19 context, there is no human-rights based framework or system of social protection in place in Sudan to ensure access to core ESCR, such as the rights to food, adequate housing, the highest mental and physical health, and accessible education. Sudan's national legislative framework surrounding ESCR is weak in ensuring social protection for the populace to be able to assert an entitlement to any legal rights. Hence, in view of the adverse consequences of COVID-19, it becomes urgent to assess Sudan's social protection and social security legislation. This includes the right to work and employment, labourrelated laws such as the Labour Act (1997), ${ }^{26}$ Trade Unions Act (2010), Domestic Servants Act (1955) and other legislation regulating both the private and informal sectors, the Social Insurance Act (1999, as amended in 2004 and 2008), the Social Insurance and Pension Act (2016) and the Health Insurance Act (2016) with its limited coverage. These laws provide some relevant regulation but are deficient, not least because they are not specifically tailored towards ensuring ESCR protection. The social insurance and social security laws, for example, do not envisage social protection to workers, including workers in the informal economy. A huge number of people in the informal economy

24 "Sudan economic outlook: Recent macroeconomic and financial developments" (African Development Bank Group), available at: < https://www.afdb.org/en/countries/eastafrica/sudan/sudan-economic-outlook> (last accessed 14 August 2021).

25 See statement of Idriss Jazairy, special rapporteur on the negative impact of unilateral coercive on the enjoyment of human rights: "UN special rapporteur welcomes US decision to lift Sudan sanctions" (9 October 2017, Office of the UN High Commissioner for Human Rights (OHCHR)), available at: <https://www.ohchr.org/EN/NewsEvents/Pages /DisplayNews.aspx?NewsID=22216\&LangID=E $>$ (last accessed 14 August 2021).

26 The Labor Act expressly excludes from its ambit certain categories that could well fall under "workers", such as family members of employers, agricultural workers and domestic workers: art 3(f)(e)(g)(h)(i). 
are covered by neither the Labor Act nor the Social Insurance Act, although there is no up-to-date information on the volume and role of the informal sector in Sudan in general. The Labour Force Survey (2011) confirms that national insurance covers very few people in Sudan, at most 300,000 individuals. ${ }^{27}$ The survey further shows that only 12 per cent of the population have social security protection, while 18 per cent have health insurance. ${ }^{28}$ These are concerning figures that require serious attention from law and policy makers. ${ }^{29}$ The UN Committee on ESCR is concerned at the extent of the informal economy in Sudan, in which labour, trades union and social security rights are not protected. ${ }^{30}$ It recommends that Sudan address regulatory and administrative barriers to the creation of employment in the informal economy and take measures to enforce labour regulations progressively. ${ }^{31}$

One of the social protection laws worth mentioning is the Zakat Act (2001). ${ }^{32}$ Zakat (alms tax) is regarded as the first institution offering protection and social security in Sudan to achieve social justice, by shifting financial resources from the better-off to disadvantaged groups in society. The philosophy of Zakat is focused on collecting funds by taking a fixed amount of a person's wealth for spending on specific groups, in particular the poor and needy. In Sudan, the government argues, the obligation of Zakat is viewed as a social security mechanism embodying the state's concerns to instil a sense of solidarity and mutual human understanding among individuals in a society where the rich help the poor. ${ }^{33}$ According to the government, Zakat in Sudan "has become a prominent hallmark of the state's social fabric and is widely given in all states, local communities and regions, both rural and urban, thereby reaching those who are eligible for it". ${ }^{34}$ It also supports health projects, including the supply of rural hospitals in the states, education projects,

27 See I Ibrahim "Decent work: Challenges and horizons - A reading on the Labor Force Survey 2011" (analytical paper presented at the Symposium on Analysis of the Findings of the Labor Force Survey 2011, Khartoum, January 2013) at 12-13 (in Arabic).

29 The percentage of females involved in informal activities in Khartoum State was estimated at 56\%: A Roadmap Toward, above at note 21 at 16-17.

30 "Concluding observations", above at note 11, para 33.

31 See ILO "Transition from the informal to the formal economy recommendation" (2015, recommendation no 204).

32 Zakat is an Islamic finance term referring to the obligation that an individual has to donate a certain proportion of their wealth each year to charitable causes. Zakat is a mandatory process for Muslims and is regarded as a form of worship. Giving money to the poor is said to purify annual earnings that are over and above what is required to provide a person or family's essential needs. On the role of Zakat and Islamic social finance, see: A Muneeza, A Sarea and M Hassan COVID-19 and Islamic Social Finance (2021, Routledge).

33 "Consideration of reports submitted by states parties under articles 16 and 17 of the International Covenant on Economic, Social and Cultural Rights: Sudan" (second periodic report of states parties due in 2003, Committee on ESCR), UN doc E/C.12/SDN/2 (18 September 2013), paras 239-41 at para 239.

Id, para 240 . 
water projects including drilling and the installation of wells, and agricultural projects. $^{35}$

However, the Zakat system is limited in its coverage to the needy, marred with corruption and, above all, is not in harmony with the concept of ESCR: it is charitable and not grounded in any rights-based approach. The UN Committee on ESCR expressed concern that only a small fraction of the population is covered by social security in Sudan. ${ }^{36}$ The committee recommended that, besides the activities of the Zakat Fund, measures be taken to develop a social security system, based on the right to social security and with adequate public budget allocations, with a view to reaching full coverage of all segments of the population. It further recommended that Sudan consider the establishment of a social protection floor as envisaged in the International Labour Organization (ILO) Social Protection Floors Recommendation, 2012 (No 202) and referred Sudan to its General Comment No 19 (2008) on the Right to Social Security. ${ }^{37}$

The legislative framework also lacks protection with regard to the rights to adequate food ${ }^{38}$ and shelter, the right to land, ${ }^{39}$ the right to adequate physical and mental health, the right to education, the right to an adequate standard of living, and the right to adequate housing, water and sanitation, so as to enable individuals and families to enjoy the minimum core ESCR. ${ }^{40}$ Although the realization of ESCR is one of the key demands of the 2018 December Revolution, there is a lack of a comprehensive strategic vision by law and policy makers within the transitional government on the necessity to realize such rights after the outbreak of COVID-19. An important factor explaining this inadequate response is that political elites have largely ignored the social protection agenda, with the exception of the political left, which associated itself with trades union movements but has so far proved unable to articulate or conceptualize any legal reform agenda or adopt a human rights-based approach. ${ }^{41}$

In addition to the inadequacy of Sudan's legislation, a close reading of Sudanese constitutions indicates that they were not derived from any "social

35 Id, para 241.

36 "Concluding observations", above at note 11, para 37.

37 Id, para 38.

38 See "The UN special rapporteur on the right to food recommends principles and measures to discipline 'land grabbing'" (press release, 11 June 2009), available at: <www.srfood. org/images/stories/pdf/press_releases/20090611_press-release_en.pdf> (last accessed 14 August 2021).

39 See MA Babiker "Communal customary land rights in Sudan: The need for comprehensive reform of statutory land laws" in B Casciarri and MA Babiker (eds) Anthropology of Law in Muslim Sudan (2018, Brill Publishers) 125.

40 See UN Committee on ESCR General Comment 19: The Right to Social Security (Article 9), UN doc E/C.12/GC/19 (4 February 2008).

41 Babiker "Human rights protection", above at note 11. 
justice model", as is the case with other African constitutions ${ }^{42}$ and practices of foreign courts. ${ }^{43}$ The ESR components of these constitutions have been largely ignored, including by democratic regimes. ${ }^{44}$ Sudan's 1973 Permanent Constitution remains its only constitution that focused on ESCR, due to the socialist orientation of the military regime during the early $1970 \mathrm{~s} .{ }^{45}$ It covers minimum standards provided for in the ICESCR and African Charter.

The right of everyone to the enjoyment of the highest attainable standard of physical and mental health has not been a priority for national governments (neither democratic nor authoritarian) since independence. With the exception of the 1973 Permanent Constitution, which emphasized that healthcare and medical treatment are a right of every citizen that the state shall endeavour to provide for free (article 54), other constitutions barely provide for the right to health. However, article 19 of the guiding principles in the previous Interim National Constitution (INC 2005) provided that the state "shall promote public health and guarantee equal access and free primary health care to all citizens". This recognition of the right to healthcare was strengthened by article 46 of INC 2005 to the effect that the state "shall promote public health, establish, rehabilitate, develop basic medical and diagnostic institutions, and provide free primary health care and emergency services for all citizens". While international standards impose upon states an obligation to recognize the right of everyone to physical and mental health, Sudanese constitutions are confined to promoting public health for citizens. INC 2005 therefore did not recognize the right of everyone to the enjoyment of the highest attainable standard of healthcare, as set out in the ICESCR and as provided for in the African Charter, a gap that needs to be addressed in any future constitutional bills of rights. ${ }^{46}$

Sudanese constitutions are also silent with regard to the recognition of the right of everyone to an adequate standard of living, including adequate food,

42 The Constitution of South Africa, for example, is hailed as a model of a social rights constitution. See secs 1, 7(2), 10, 11, 26, 27, 28 and 39.

43 Courts in India and South Africa have creatively interpreted denial of the "right to livelihood" as amounting to denial of the right to life. In respect of Constitutional Courts in India, see Olga Tellis $v$ Bombay Municipal Corporation Supreme Court of India 1985, AIR 1986 Supreme Court 18; this case shows that courts may interpret directive principles as creating constitutional obligations. See also Soobramoney $v$ Minister of Health (Kawazulu-Natal) Constitutional Court of South Africa CCT 32/97 (27 November 1997) and Treatment Action Campaign v Minster of Health Constitutional Court of South Africa CCT 8/02 (5 July 2002).

44 See A Abdelgadir "Economic, social and cultural rights under the Constitutional Bill of Rights in the Sudan" in M Babiker and L Oette (eds) The Constitutional Protection of Human Rights in Sudan: Challenges and Future Perspectives (2014, Redress) 32.

45 A Fadlalla and MA Babiker "In search of constitution and constitutionalism in Sudan: The quest for legitimacy and the protection of rights" in Oette and Babiker (eds) Constitution-Making, above at note 11, 41.

Ibid. 
clothing and housing. ${ }^{47}$ They also fail to provide for the right to social security, including social insurance, with the exception of the 1973 Permanent Constitution, under which the state must provide a system of social security against disasters, sickness, orphanage, old age, unemployment and other causes of disability. ${ }^{48}$ However, this system was never implemented and remains mere ink on paper.

Sudan's periodic reports and statements to the UN human rights treaty bodies claim that such treaties, including IESCR, once ratified, prevail over national laws, by virtue of becoming part of domestic law, and can be invoked before all national courts in Sudan. ${ }^{49}$ Such reports and statements however belie the actual status quo of Sudan's legal system vis-à-vis human rights treaties. ${ }^{50} \mathrm{~A}$ blatant dichotomy persists between what was reported and the actual practice of executive and judicial bodies. Sudan's representatives, in order to avoid criticism, have stonewalled the issue of the implementation of human rights treaties and have tended to provide misleading or inaccurate information in the process of considering reports submitted to UN bodies. ${ }^{51}$ However, the Human Rights Committee has repeatedly questioned the implementation status of the ICESCR and ICCPR and how respect for the rights they grant can be ensured. ${ }^{52}$ The ESCR Committee, for its part, noted: "[t]here is a lack of clarity as to the legal status of the [ICESCR] in the Sudanese domestic legal order, despite the incorporation in the Constitution of some provisions concerning economic, social and cultural rights". ${ }^{53}$ The ESCR Committee also raised concern that there is lack of explicit recognition of several ICESCR rights in the constitution, that the legal provisions in the constitution are incompatible with the ICESCR and that the ICESCR has not been invoked by or before courts in Sudan. ${ }^{54}$ The committee recommended that Sudan incorporate all ICESCR rights in its constitution and undertake a comprehensive review of its federal and state laws with a view to bringing them into conformity with the ICESCR. ${ }^{55}$

47 As recognized according to ICESCR, art 11.

481973 Permanent Constitution, art 24.

49 See "Consideration of Sudan's ICCPR initial report”, supp no 40, UN doc A/46/40 (1991, UN Human Rights Committee), para 507 and "Sudan's ICCPR second periodic report”, UN doc CCPR/C/75/Add.2 (13 March 1997), paras 28 and 61.

50 See M Babiker Application of International and Human Rights Law to the Armed Conflicts of the Sudan: Complementary or Mutually Exclusive Regimes (2007, Intersentia) at 71.

51 See, for example, the claim by Sudan's representatives in the Human Rights Committee: "under the Sudanese legal system once an international instrument was ratified, it became part of domestic law. The Covenant did have precedence over domestic legislation because the Sudan was a party to the 1969 Vienna Convention on the Law of Treaties": "Consideration of Sudan's second periodic report", UN doc CCPR/C/SR.1629 (31 November 1997), para 68.

52 "Consideration of Sudan's ICCPR", above at note 49, para 495.

53 See "Concluding observations", above at note 11, paras 5-8.

54 Ibid.

55 Ibid. 
In the regional human rights system, the African Commission on Human and Peoples' Rights has dealt with a number of communications concerning the implementation of the African Charter in Sudan. ${ }^{56}$ The majority of those communications have dealt with civil and political rights, such as torture, arbitrary arrest and detention, summary executions, violations against Christians, closure and destruction of churches, ${ }^{57}$ violations of the right to personal liberty and security of the person, ${ }^{58}$ and dismissal of judges. ${ }^{59}$ However, some communications against Sudan involved ESCR, including a case related to denial of the right to education that the commission declared inadmissible due to non-exhaustion of the local remedies. ${ }^{60}$

In summary, a review of Sudan's constitutions and laws demonstrates that ESCR have been neglected, if not altogether ignored, by both civilian and military governments. These include the Constitutional Declaration 2019, which does not include justiciable ESCR even though social justice was one of the key slogans of the 2018 revolution. It could be argued that international treaties such as the ICESCR and African Charter are an integral part of the Constitutional Declaration and hence justiciable in Sudan. Courts in other jurisdictions have adopted creative approaches to realizing ESCR. ${ }^{61}$ It is now imperative that the recognition and adequate protection of ESCR is seen as one of the priorities for Sudan's future constitution, particularly after the COVID-19 pandemic has affected the lives and livelihoods of millions of vulnerable Sudanese who do not enjoy minimum core ESCR. If minimum core ESCR are not guaranteed, the right to survival of hundreds and thousands of Sudanese, particularly the poor and vulnerable groups, will be at risk in the immediate future, if not for years to come.

56 Amnesty International $v$ Sudan, comm no 48/90; Comité Loosli Bachelard $v$ Sudan, comm no 50/91; Lawyers Committee for Human Rights $v$ Sudan, comm no 52/91; Association of Members of the Episcopal Conference of East Africa $v$ Sudan, comm no 89/93 (Algiers, Algeria, 11 May 2000) published in (2001) 8/1 International Human Rights Reports.

57 Comm 89/ 93 (2001) 8/1 International Human Rights Reports at 259, paras 18 and 20.

58 Comm 48/90; comm 50/91 (2001) 8/1 International Human Rights Reports at 256-57 and 292.

59 Comm 52/91 (2001) 8/1 International Human Rights Reports at 258-59, paras 16-17.

60 See, for example, Law Offices of Ghazi Suleiman $v$ Sudan, comm no 220/98 (31st ordinary session, Pretoria, South Africa, 2-16 May 2002) (2003) 10/1 International Human Rights Reports at 8, paras 3, 4, 6, 7, 35, 37, 39, 41 and 42 (summary of facts) and at 275-78. In this communication, the minister of education announced on 26 September 1998 that all universities would be closed to assist the military mobilization for the armed conflict in southern Sudan. The complainant requested the commission to adopt provisional measures under rule 111 of its Rules of Procedure, which would request the government of Sudan to re-open the universities and prevent further interference with university teaching. The complainant informed the commission (at 275-76, paras 3-4) that "no effective recourse was available and that, even if used, the Constitutional Court is not qualified due to the state of emergency and the political limitations, which makes it impossible to legitimately complain to the court".

61 Y Ghai and J Cottrell (eds) Economic, Social \& Cultural Rights in Practice: The Role of Judges in Implementing Economic, Social \& Cultural Rights (2004, Interights). 
The lack of provision of ESCR might equally affect the democratic transition in Sudan, which remains fragile and volatile. As a nascent and emerging democracy, Sudan should follow a participatory, whole-of-government and whole-of-society approach in responding to the socio-economic challenges of COVID-19. A human rights friendly budget allocation to vulnerable groups and the poor will reduce inequality, help create a social contract of mutual accountability between the state and citizens, and prevent large numbers of people from falling into destitution. ${ }^{62}$ Also, enhancing social protection schemes grounded in human rights-based approaches and improved access to a basic but robust health system will safeguard vulnerable populations against preventable death and poverty. ${ }^{63}$

\section{COVID-19 AND THE POLITICAL TRANSITION}

\section{An analysis of emergency measures}

Sudan's transitional government responded to the outbreak of COVID-19 with emergency health measures to prevent the spread of the disease. It also formed the Central Health Emergency Committee in March 2020, which was vested with emergency powers and mandated under the constitution to control the pandemic. ${ }^{64}$

Sudanese constitutions traditionally provide wide discretion to the executive branches to declare national emergencies and to determine whether danger is imminent, as was the case in the 1998 National Constitution ${ }^{65}$ and the Interim Constitution of 2005.66 Under the Constitutional Declaration 2019, when a state of emergency is in effect, the Cabinet of Ministers has constitutional powers to "take any measures without restriction, or may partially repeal or limit the effects of provisions of the Constitution". ${ }^{67}$ If the exceptional or emergency situation reaches the point that it threatens the safety

62 Realizing Human Rights Through Government Budgets HR/PUB/17/3 (September 2017, OHCHR); Human Rights in Budget Monitoring, Analysis and Advocacy: Training Guide (March 2020, OHCHR).

63 See Committee on ESCR, General Comment No 14: The Right to the Highest Attainable Standard of Health (Article 12 of the ICESCR), UN doc E/C.12/2000/4 (11 August 2000).

64 "Sudanese Health Committee recommends extending lockdown of Khartoum State" (7 May 2020) Reuters (in Arabic), available at: <https://www.reuters.com/article/instantarticle/idARAKBN22J3G0> (last accessed 14 August 2021).

65 Art 131(1) gives the president of the republic wide discretion to determine states of emergency: he "may, upon the occurrence or approach of any emergent danger, whether it is war, invasion, blockade, disaster or epidemics, as may threaten the country, or any part thereof or the safety or economy of the same declare the state of emergency in the country, or in any part thereof, in accordance with the Constitution and the law".

66 Before South Sudan's independence, the only difference from the 1998 Constitution was that the consent of the first vice-president was required before the president could declare an emergency or war: art 210 (declaration of state of emergency); art 211 (powers of the president in a state of emergency).

67 Art 40. 
of the nation, the Cabinet may, in consultation with the Sovereign Council, suspend part of the Bill of Rights in the Constitutional Declaration, including ESCR and health rights. ${ }^{68}$ However, it may not derogate from "the right to life, protection from enslavement or torture, or the principle of nondiscrimination on the basis of race, gender, religious conviction, disability, the right to litigate or the right to fair trial". ${ }^{69}$

In order to contain the spread of COVID-19, the transitional government used its emergency powers to restrict freedom of assembly and association by banning some public demonstrations organized by youth groups, victims' groups, women's organizations, war-affected communities and resistance committees. It may be argued that such emergency measures could negatively impact the fragile political and democratic transition in Sudan. However, the current political transition in Sudan was meant to guarantee democratic participation and rights. Also, the emergency measures were not intended to stifle criticism. Nor did they reflect the old habits of the previous dictatorial regime and its abhorrent legacy of human rights violations in restricting the civic space to thwart the political transition altogether. Rather, it could be justifiable for the government to ban demonstrations to contain the spread of the pandemic, provided that would not adversely impact political freedoms and the democratic transition. Epidemics have been considered to be one of the legitimate grounds for derogations and are often asserted as grounds for declaring a state of emergency; they usually represent one of the prototypes of a public emergency that threatens the life of a nation. ${ }^{70}$ Indeed, a number of states have adopted states of emergency in response to COVID-19. ${ }^{71}$ Without doubt, however, such measures must be proportional in degree and duration, and strictly required to deal with the threat to "the life of the nation". ${ }^{2}$

From an ESCR-based perspective, COVID-19 emergency measures have seriously affected the enjoyment of core ESR, including the rights to health, education and work, and the daily livelihoods of vulnerable populations living below the poverty line. Peoples' right to work was restricted while access to health services was diminished due to the diversion of vital resources to deal with the pandemic. Grass roots organizations and informal workers (including unions of tea sellers) have criticized the government, in that lockdown has affected their daily survival and their right to lead a dignified life,

68 Ibid.

69 Ibid.

70 See, for example, Human Rights Committee General Comment No 29: State of Emergency (Article 4), UN doc CCPR/C/21/Rev.1/Add.11 (31 August 2001), para 3.

71 See "Emergency measures and COVID-19: Guidance" (27 April 2020, OHCHR), available at: <https://www.ohchr.org/Documents/Events/EmergencyMeasures_Covid19.pdf> (last accessed 14 August 2021). See also statement of the UN High Commissioner for Human Rights: "Coronavirus: Human rights need to be front and centre in response, says Bachelet" (Geneva, 6 March 2020), available at: <https://www.ohchr.org/EN/NewsEvents/Pages/Displ ayNews.aspx?NewsID=25668\&LangID=E $>$ (last accessed 14 August 2021). General Comment No 29, above at note 70, para 3. 
while the government failed to cater for their basic needs. ${ }^{73}$ Such criticism probes the ethos of declaring a state of emergency in response to COVID-19. It raises the question of whether the mere existence of a pandemic precludes the application of human rights treaties and hence give states carte blanche to derogate, particularly in situations where the state violates or restricts the enjoyment of core rights in the ICESCR rather than the ICCPR. Without doubt, such emergency situations create "an insurmountable dilemma" for governments because, on the one hand, governments are under an obligation to protect the integrity of the state and control health epidemics, while, on the other, they are under an obligation to protect rights and freedoms. ${ }^{74}$ This represents an uneasy compromise between the protection of citizens' rights and a state's control over domestic affairs. ${ }^{75}$ Consequently, "[i]nternational law is thus faced with the challenge of finding a middle course between the recognition of the legitimate right of states to defend their constitutional order and the prevention of misuse of the right of emergency merely to maintain de facto positions of power". ${ }^{76}$ In this context, maintaining the right balance can arguably be best achieved in democratic societies where the rule of law and constitutionalism prevail.

In countries like Sudan that are emerging from authoritarianism and in a fragile political transition (where power and wealth are still shared with the military), it might not be possible to observe the rule of law and constitutionalism. In Sudan, the declaration of a state of emergency is a normal practice, which has historically been imposed by democratic, military regimes and transitional governments. Since its independence in 1956, Sudan has been ruled by exceptional powers. ${ }^{77}$ It has either been ruled under a state of emergency or there have been such substantial exceptional powers on the statute books that de facto emergency rule has been in place. ${ }^{78}$ The Human Rights Committee was not notified as required under article 4 of the ICCPR when Sudan declared states of emergency. In light of this history, it makes sense to regard emergency powers as Sudan's de facto constitution. ${ }^{79}$ This practice of "exceptionalism" has been used to try to justify serious deviations from the rule of law and has become a charter for the abuse of basic human

73 See "The state policies in Sudan continue to undermine women and marginalized communities" (20 April 2020, Strategic Initiative for Women in the Horn of Africa), available at: <https://sihanet.org/the-state-policies-in-sudan-continue-to-undermine-women-andmarginalized-communities/?fbclid=IwAR0GDp9VJpRzZPA-43xh-ARpF8KfTJDnhlAEKJMiHzaZHA10Sgzy0grY4k> (last accessed 14 August 2021).

74 G Alexander "The illusory protection of human rights by national courts during periods of emergency" (1984) 5 Human Rights Law Journal 2 at 3.

75 F Hartman "Derogation from human rights treaties in public emergencies" (1981) 22 Harvard International Law Journal 11 at 12.

76 M Nowak ICCPR Commentary: UN International Covenant on Civil and Political Rights (2nd ed, 2005, NP Engel Verlag) at 74.

77 See Babiker Application of International and Human Rights, above at note 50.

78 Ibid.

79 Ibid. 
rights. ${ }^{80}$ While the primary focus in this regard has been on the violation of civil and political rights, the imposition of the state of emergency to combat COVID-19 has brought into relief both this set of rights and ESCR as pivotal joint human rights concerns.

\section{The Transitional Legislative Council and COVID-19}

The state of emergency to control COVID-19 was declared by the transitional government. As in the case under previous Sudanese constitutions, the Constitutional Declaration 2019 provides for specific procedures governing such a declaration of an emergency. It states: "[u]pon the occurrence of any emergent danger or natural or environmental disaster that threatens the unity of the country, or any part thereof, or its safety or economy, the Cabinet of Ministers may ask the Sovereignty Council to declare a state of emergency in the country or any part thereof, in accordance with the Constitutional Declaration and the law". 81

Any declaration of emergency has to be presented to the TLC within 15 days from the date of its issue. If the TLC is not in session, an emergency session is to be convened. ${ }^{82}$ Upon the TLC's ratification of the declaration of the state of emergency, all exceptional laws, orders and measures issued under it remain in force. ${ }^{83}$ Conversely, the declaration of emergency lapses if the TLC does not ratify it, and all the measures taken under it are invalidated or cease to be valid without retroactive force. ${ }^{84}$ However, the TLC has still not been formed over a year after the 90 days from the date of the signing of the Constitution Declaration in August 2019, despite the constitutional stipulation that it be in place. ${ }^{85}$ Instead, the executive Sovereign Council and the Cabinet of Ministers have, in joint sessions, continued to enact and pass key legislation that is important for the democratic transition. They did not follow constitutional procedures when they imposed the health emergency that was declared due to the outbreak of COVID-19 in Sudan, due to the fact that the TLC was not in place to validate and control that declaration.

In the absence of the TLC and pending its formation, all legislative and emergency powers remain in the hands of the Cabinet of Ministers and the Sovereign Council, with no possibility for those emergency powers to be challenged. This unconstitutional practice is in place even though the TLC is the

80 Justice Africa / Committee of the Civil Project "Constitutional challenges of the transition" in A Abdel Salam and A De Waal (eds) The Phoenix State: Civil Society \& the Future of Sudan (2001, the Red Sea Press) 2.

81 Constitutional Declaration 2019, art 39(1), chap 13 (state of emergency). Although in this article epidemics or pandemics are not included as one of the grounds for the declaration of a state of emergency, the transitional government can still declare a state of emergency due to the COVID-19 pandemic if it threatens the life of the nation.

82 Id, art 39(2).

83 Id, art 39(3).

84 Id, art 39(4).

85 This amounts to a constitutional violation of id, art 23(4). 
only law-making body entrusted with endorsing a state of emergency. This is incompatible with established constitutional norms and the constitutional framework regulating the declaration and termination of a state of emergency provided for under the Constitutional Declaration 2019. It also compounds the lack of democratic legitimacy and deliberation and executive dominance that the formation of the TLC was meant to prevent during the transitional period. COVID-19 has contributed to the delay in the TLC's formation by both slowing down political decision-making generally and providing the pretext for the continuation of executive rule.

\section{The Constitutional Court and COVID-19}

In the absence of a Constitutional Court, emergency declarations are not subject to the judicial review that the court was tasked with exercising under the Constitutional Declaration 2019.86 As with the case of the TLC, the court has not yet been established to review the legality of the declaration of an emergency in cases where the executive branch of government is alleged to have exceeded its constitutional boundaries. ${ }^{87}$ The court's formation and the selection of its judges are currently pending, as they depend on the formation of the High Judicial Council that will replace the existing National Judicial Service Commission. However, it is pertinent to note that, historically, the judiciary played a limited role in controlling a state of emergency. Courts have given the executive branches of government wide discretion or a margin of appreciation to declare a state of emergency and tend to support the principle that a declaration of emergency is an internal sovereign act. ${ }^{8}$ Case law in Sudan confirms this practice. In one of the landmark cases, the previous Constitutional Court held that the president's actions were consistent with the constitution because "he did not contravene the required procedures in declaring the state of emergency" ${ }^{89}$ According to this jurisprudence, courts

86 Id, art 20(1) (challenging actions of the Sovereign Council and Cabinet) provides: "Anyone harmed by the actions of the Sovereign Council or Cabinet may challenge the same before (a) The Constitutional Court, if the challenge is directed at any infringement of the constitutional order or constitutional freedoms, protections or rights and (b) if the challenge is directed at violation of the law."

87 Furthermore, id, art 30(1) provides that the Constitutional Court is an independent court, separate from the judicial authority. It is competent to oversee the constitutionality of laws and measures, protect rights and freedoms, and adjudicate constitutional disputes. The Interim Constitutional Document 2019 provides for its creation within 90 days after the adoption of the Interim Constitution.

88 For a critical analysis of the margin of appreciation doctrine of emergency, see Ghai and Cottrell (eds) Economic, Social \& Cultural Rights, above at note 61.

89 Ibrahim Yusif Habani and Others $v$ President of the Republic. In this case, the president's powers were challenged in the Constitutional Court. Following a dispute between the president and the National Assembly (Parliament), he declared a state of emergency throughout the country and dissolved the Assembly under the 1998 Constitution, art 43(d). As a result, some members of Parliament challenged his decisions on 28 December 1999, arguing that he had violated the National Constitution since: he 
should not involve themselves in crises caused by political disputes among state institutions..$^{90}$ The president represents the ultimate sovereignty of the country and is in charge of protecting its security, particularly in cases of an emergent danger or disturbance or expected disaster. ${ }^{91}$

This practice prompts legitimate concerns about the role of Sudan's Constitutional Court as its predecessors traditionally ruled in favour of the executive. It raises the question of whether its absence, and consequent ability to review emergency powers, will make a difference in practice. After the successful peaceful revolution of 2018, the Sudanese people are now hopeful that the new forthcoming court will uphold the rule of law by subjecting government to appropriate constitutional scrutiny. However, the absence of the court has prevented the very scrutiny of far-reaching COVID-19 emergency measures, particularly the constitutionality of laws, the right to participate in public life, as well as the right to work and the right to health, which were affected by the lockdown and health emergency measures. ${ }^{92}$

In summary, the transitional government is not subject to parliamentary scrutiny or indeed scrutiny by the Constitutional Court, and exercises legislative powers that are de facto illegitimate. Without doubt, this status quo raises critical questions of legality, constitutionalism and the rule of law, due to the seemingly deliberate delay in the formation of both the TLC as an important transitional body and the Constitutional Court. This incomplete governance structure is concerning and has prevented scrutiny of COVID-19 emergency measures, executive decrees or decisions. This applies particularly to decisions affecting basic ESCR of vulnerable groups in society, including the right to receive essential health treatment and lifesaving drugs, labour rights and other civil and political rights outlined above. ${ }^{93}$

contd

unlawfully dissolved the Assembly before its mandate had expired; the declaration of public emergency was not submitted to the National Assembly for approval under art 131(2) of the constitution; and he had no right to suspend some of the constitution's articles concerning appointments and the demotion of federal state governors from holding office. See judgment of 8 March 2000, case no MD/GD/1/2000, para 10 at 14 (author's translation). For an analysis of this case, see I Bantekas and H Abu-Sabeib "Reconciliation of Islamic law with constitutionalism: The protection of human rights in the Sudan's New Constitution" (2000) 12 African Journal of International and Comparative Law 531 at 544-46.

90 In justifying this approach, the court cited two Sudanese cases: Khalid Mohamed Khair $v$ the Government of the Sudan (1987) Journal of Judicial Decisions 404 and James Okolo $v$ the Government of the Sudan (1987) Journal of Judicial Decisions 15.

91 Habani $v$ President of the Republic, above at note 89, para 10 at 15.

92 See section above on "The Constitutional Court and COVID-19".

93 See sections above on "The Transitional Legislative Council and COVID-19" and "The Constitutional Court and COVID-19". 


\section{Independent commissions, consultations and COVID-19}

The Constitutional Declaration 2019 provides for the establishment of independent and autonomous commissions to be formed by the prime minister ${ }^{94}$ and the Sovereign Council. ${ }^{95}$ They are mandated to support the democratic transition in Sudan and are to be composed of persons of attested competence, integrity and independence. ${ }^{96}$ The rationale behind establishing these constitutional commissions is to realize the revolution's objectives during the transitional period. ${ }^{97}$

As with the TLC and the Constitutional Court, the formation of these independent commissions was delayed, with the exception of three commissions, the laws establishing which were passed in April 2021.98 These commissions were formed without wide consultative and participatory processes. The Transitional Justice Commission Act 2021 was drafted by the government but has been the subject of neither democratic deliberation (in the absence of the TLC) nor public consultation. It remains an area of significant disagreement between the government and civil society. ${ }^{99}$ The government's approach is that the Transitional Justice Commission should be established and then be responsible for undertaking a broad national consultation on the design and implementation of various transitional justice measures in Sudan. Civil

94 According to art 38(5), these commissions include: Legal Reform Commission; Anti-Corruption and Public Funds Recovery Commission; Human Rights Commission; Civil Service Reform Commission; Law Reform Commission; Land Commission; Transitional Justice Commission; Women and Gender Equality Commission; and any other commissions that the Cabinet deems it necessary to establish.

95 Under the Constitutional Declaration 2019, art 38(2) and (3), the Sovereign Council will appoint the chairman and members of four key and essential commissions: Peace Commission; Borders Commission; Constitution-Making and the Constitutional Conference Commission; and Elections Commission. It is pertinent to note that this will give the military more powers over such key commissions to determine the outcome of the transitional period in Sudan, as the military will be in a better position to manipulate the work of the commissioners and the law establishing such commissions.

96 The requirements include: academic qualification and practical expertise in the relevant field; to have not held sovereign or constitutional positions during the period of rule from June 1989; and neutrality, integrity, competence and professional independence: id, art 38 and 38(b).

97 See M Babiker "Independent legal opinion on the constitutional decree and the political agreement between the Transitional Military Council and the forces of the Declaration of Freedom and Change to establish the structures and institutions of governance in the transitional period" (15 July 2019, unpublished).

98 These commissions are the Transitional Justice Commission, Peace Commission, and the Anti-Corruption and Public Funds Recovery Commission, as published in the Ministry of Justice Official Gazette (17 July 2021).

99 The Transitional Justice Commission Bill 2020 was submitted to the Cabinet of Ministers in July 2020. The Sudanese Civil Society Coalition for Transitional Justice requested the prime minister to postpone the introduction of the law to the joint meeting of the Council of Ministers and Sovereignty for final approval without meaningful consultation and wide public participation. 
society organizations hold the view that broad national consultations should take place before any legislation is finalized, so that the law can be as comprehensive as possible. ${ }^{100}$ The government's approach to date suggests that the transitional government is adopting an "elitist top-down approach", justified on the grounds that COVID-19 impacted the public civic space. While the government expressed the hope of holding broader public consultations, the pandemic, it claimed, made such discussions impossible due to the strict health requirements of social distancing and restrictions on holding public gatherings. In the absence of government-led consultations, civil society networks have created spaces for public consultations, including active engagement from victims and youth groups. Notably, these efforts have made effective use of online communications and platforms. The government's nonconsultative approach has demonstrated a lack of imagination for using alternative approaches, if not betrayed an intention to use the COVID-19 situation as a means to progress its plans with the least possible public scrutiny. The government therefore risks undermining the legitimacy of the transitional justice process before it has even commenced. The COVID-19 contingency, while clearly temporary, has in these circumstances impacted significantly on the format and process of a fundamental component of Sudan's transition.

\section{CONCLUSION}

This article has identified four major legal, particularly human rights, dimensions of responses to COVID-19 in Sudan. First, as in many other countries on the continent and worldwide, the pandemic has constituted a major test of the state of Sudan's health system and the protection of the right to health. Due to chronic underinvestment, the absence of ESCR budgeting and the inadequate protection of the right to health, Sudan's health system has struggled to provide basic health services. At the time of writing in July 2021, Sudan has a low rate of vaccination against COVID-19 due to limited supplies, ${ }^{101}$ which means that ongoing pressures on the health services are likely to persist for some time. Secondly, weak social determinants of health, such as poverty, inequality and multiple vulnerabilities, have aggravated the structural impact of COVID-19 on lives and livelihoods in Sudan. The absence of adequate ESCR protection in Sudan's legislative framework has therefore exacerbated the

100 "National perception study of transitional justice in Sudan" (September 2020, Sayara International for USAID), available at: <https://sayarainternational.com/wp-content/uplo ads/2020/12/Sayara-for-DT-Sudan-Transitional-Justice-Final-Report.pdf> (last accessed 14 August 2021).

101 Sudan received the Oxford-AstraZeneca vaccine in early March 2021 through the COVAX programme and began its vaccination campaign on 9 March. The priority target groups for vaccination are healthcare workers at all levels of the health service, persons aged 60 and over, and patients with comorbidities aged 45 and over. However, more vaccine supply is desperately needed. See Mukhtar and Khogali "The accelerating COVID-19 epidemic", above at note 2 . 
vulnerability of large sectors of the population and meant that the state lacked the legal structures and tools to respond to the pandemic. Due to the political transition, other priorities and various delays (which can be partially attributed to COVID-19), the transitional government has so far failed to put in place an adequate, rights-based legislative framework to protect ESCR. Thirdly, the state of emergency declared in response to the outbreak of COVID-19 in Sudan has, in the absence of adequate ESCR protection, compounded adverse social determinants of health and further enhanced poverty and precarity. The government has, in an ongoing economic and financial crisis, not responded adequately to meet the challenges resulting from the various restrictions imposed, which are likely to have long-term consequences for the protection of ESCR in Sudan.

Fourthly, in what are unique lessons from Sudan, the pandemic has impacted the political transition, raising complex questions of the relationship between public health measures, reforms and rights protection. The COVID-19 challenges have led to a revival of modes of emergency rule and contributed to the slowing down of envisaged reforms. Importantly, however, the lack of such reforms, such as the formation of the TLC and the establishment of the Constitutional Court and various commissions, in addition to legislative changes, has weakened democratic deliberation, scrutiny and judicial oversight. The resulting legislative and institutional weakness has not only raised concerns about the adverse consequences for the rule of law and human rights protection during the transition. It has also arguably hampered a more concerted effort to respond to the COVID-19 related challenges prevailing in Sudan. The analysis of Sudan's response to COVID-19 to date demonstrates the importance of taking a structural, legislative and institutional approach that situates public health related (emergency) measures in a broader spectrum of interrelated human rights.

\section{CONFLICTS OF INTEREST}

None 